\title{
Understanding how university student perceptions of resources affect technology acceptance in online learning courses
}

\author{
Stephen Anthony Sivo \\ University of Central Florida, Orlando, USA \\ Cheng-Hsin Ku \\ Soochow University, Taipei, Taiwan, China \\ Parul Acharya \\ Columbus State University, Georgia, USA
}

The purpose of this empirical research was to use the perceived resources and technology acceptance model (PRATAM; Ku, 2009) to observe and measure students' beliefs on using the WebCT online learning system (OLS) in two WebCT courses offered at a large university in the south-eastern United States. PRATAM was replicated from previous research to address the factors of perceived resources (R), perceived usefulness (U), perceived ease of use (EOU), attitude towards using, behavioural intention to use (BI), and actual system use (USE). The results show that the constructs of PRATAM explained the data well in both surveys conducted. This study makes a contribution to the literature on PRATAM by identifying and understanding the factors that influence students' behaviours in response to the OLS. Moreover, it provides insights for administrators and instructional designers for improving students' persistence and retention in online learning courses.

\section{Introduction}

In higher education, the implementation of information and communication technologies (ICTs) has become widespread from applying for courses, registering for courses, taking classes, to composing assignments and communicating with instructors and cohorts. The main reason behind the implementation is the expectation of enhancing the quality of communication and teaching and improving student learning and persistence (Nora \& Snyder, 2009). One of the most noticeable implementations in higher education is online learning (OL). Unlike traditional face-to-face learning, which requires students to come to a physical classroom with supervision at a particular time, OL utilises ICTs, enabling students to pick their favourite time and location, and even use their own personal computers to access the course content.

However, since the nature of OL relies heavily on students voluntarily accessing and interacting with the computer and the Internet technology, a good student in a traditional face-to-face class may not necessarily be a good student in OL, and vice versa. Researchers suggest that one of the biggest challenges for OL is student retention (Clay, Rowland, \& Packard, 2009). Researchers also warn that the attrition rate for online courses is significantly higher than in traditional courses (Diaz, 2002; Wells, 2007). What we know regarding teaching, learning and motivation from face-to-face classes might not be appropriate for the OL environment. There are few studies that provide explanations on students' behaviours specific to the World Wide Web Course Tools (WebCT) online learning system (OLS) (Pituch \& Lee, 2006). Understanding the factors that influence students' behaviours in the OL environment is becoming critical for administrators and instructional designers with regard to improving student persistence and future OL expansion.

The present study identifies and examines the factors that influence students' behaviours in using a Webbased course in a large south-eastern university in the United States. A theory-based perceived resources and technology acceptance model (PRATAM; Ku, 2009) was proposed to examine students' perceived resources (R), perceived usefulness (U), perceived ease of use (EOU), attitude towards using, and behavioural intention (BI) as predictors of the usage behaviours in OL courses. The technology acceptance model (TAM; Davis, 1986) has been widely applied to explain and predict the intended usage and acceptance behaviours in OL 
(Turner, Kitchenham, Brereton, Charters, \& Budgen, 2010; Venkatesh \& Davis, 2000). However, researchers have commented that the TAM framework has not been applied to WebCT (Ngai, Poon, \& Chan, 2007).

\section{Review of literature}

\section{Online learning systems}

OL is an enhanced e-learning method which involves training, education, coaching, information and any learning content that is delivered digitally or electronically (Fallon \& Brown, 2003). OL applications, such as chat sessions, posts and emails, facilitate communication between instructors and students in various ways (Romanov \& Nevgi, 2006). Institutions provide a more flexible, interactive, rich, engaging, and easy-to-use learning environment to support students in collaborative learning, knowledge building and the sharing of ideas (Lu, Yu, \& Liu, 2003) through the adoption of OL. OLSs (also known as course management systems) are software systems that are specifically designed for faculty and students (Morgan, 2003). An OLS provides the accessibility and scalability of learning content, one-to-one learner central instructions, and a trial and error simulation environment. Many universities have already contracted with OLS providers such as WebCT, Blackboard and Moodle to facilitate online instruction and enhance student OL (Ngai et al., 2007).

Blackboard, Whiteboard, Moodle, and WebCT are popular learning management systems (LMSs) which are usually used by institutes of higher education. "LMS is a self-contained webpage with embedded instructional tools that permit faculty to organise academic content and engage students in their learning" (Gautreau, 2011, p. 2). Research has examined these systems to study student outcomes such as perceptions (Kinash, Brand, \& Matthew, 2012), motivation (Deng \& Tavares, 2013), effectiveness (Novo-Corti, Varela-Candamio, \& RamilDiaz, 2013), usage and acceptance (Porter, 2013). Research has also been conducted on course management system (CMSs), which are subsumed by LMSs. A CMS is primarily used by educators to distribute information to students and prepare and organise course material, assignments, and projects and also to collaborate with other academics through posts, forums, and messages. CMSs have also been examined on different dimensions of student perception, usage, quality of e-courses, and performance in an online environment. Horvat, Dobrota, Krsmanovic, and Cudanova (2015) examined differences in student perceptions of and satisfaction with Moodle and found that females gave more importance to the quality of course material, feedback, waiting time and user-friendliness. Wei, Peng, and Chou (2015) found that usage of interactive tools and students' perceived and actual usage logs in Blackboard and Moodle influenced students' OL performance.

\section{Challenges for OL}

There is minimal technical support available for ordinary people, who are usually the main users of most OLSs. Willett (2002) found that various technical difficulties, such as system incompatibilities, firewalls, software design, human error, poorly designed courses, lack of student support, and insufficient knowledge, could be barriers for students to interact with and learn from OLSs. The frustrations caused by perceived or real technical difficulties, therefore, might influence students' beliefs, attitudes, intentions and behaviours towards using WebCT. The other challenge for OLSs is the consistently high drop-out rates (Pan, Sivo, \& Goldsmith, 2016; Wells, 2007).

\section{Theoretical approaches to student perceptions, learning and performance in an online environment}

Most of the theoretical frameworks used in OL literature are motivated by constructivist and social learning theories. "The sociocultural perspective informs theories of the conditions for the possibility of learning, whereas theories developed from the constructivistic perspective focus on what students learn and the processes by which they do so" (Cobb, 1994, p 13). Studies have utilised social learning theory to study student outcomes, such as students' online participation in hybrid learning environments (Huang, Lin, \& Huang, 2012), participation types, and learning styles (Shaw, 2012). The community of inquiry framework is 
another theoretical approach based on collaborative constructivist principle (Shea et al., 2014). Researchers have used this framework to study various facets of student learning in online and blended environments (Shea et al., 2014; Taylor, 2016; Traver, Volchok, Bidjerano, \& Shea, 2014).

Other theoretical models, such as task technology fit model (Venkatesh, Morris, Davis, \& Davis, 2003), theory of reasoned action (Fishbein \& Ajzen, 1975), theory of planned behaviour (Saade, He, \& Kira, 2007), social cognitive theory (Bandura, 1986), and TAM (Venkatesh \& Davis, 2000), have been utilised to study students' attitude, perception of and behaviour towards OL. Further, they have been applied to examine student-related outcomes in OL (D’Ambra, Wilson, \& Akter, 2013; Doyle, Garrett, \& Currie, 2014; Guiffrida, Lynch, Wall, \& Abel, 2013). In our study, we utilised TAM to understand the factors that influence students' behaviours towards WebCT.

\section{TAM}

TAM is used to describe "computer usage behavior across a broad range of end-user computing technologies and user populations” (Davis, Bagozzi, \& Warshaw, 1989, p. 985). It has become the most widely applied model for explaining and predicting usage intentions and acceptance behaviours of ICTs (Kim, 2008; Pan, Gunter, Sivo, \& Cornell, 2005; Park, 2009). For more than two decades, TAM has been accepted as a valid and simple model for predicting the acceptance of ICTs (Davis et al., 1989; Liu, Chen, Sun, Wible, \& Kuo, 2010; Lu et al., 2003; Pan, Sivo, \& Brophy, 2003; Sivo, Pan, \& Brophy, 2004; Sivo, Pan, \& Hahs-Vaughn, 2007; Wong, Teo, \& Russo, 2011).

TAM is based on the theory of reasoned action (TRA; Fishbein \& Ajzen, 1975). TRA assumes that human behaviour is the outcome led by behavioural intentions. It is the degree of an individual's intention to perform a specified behaviour. The intentions are influenced by attitude (A) and subjective norms (SN), which are formed from behavioural and normative beliefs (Fishbein \& Ajzen, 1975). The theory of planned behaviour (TPB; Ajzen, 1985) is an extension of the TRA, which incorporates perceived behavioural control as the additional determinant on users' behavioural intentions and actual behaviour (Madden, Ellen, \& Ajzen, 1992). TPB assumes that when people believe they are in control of their own behaviour, their intention to perform that behaviour will likely increase whether or not their attitudes about that behaviour are favourable. TRA and TPB have been used to explain and predict human behaviour in specific situations, including the OL behaviours of students (Chen et al., 2013; Pan, Sivo, Gunter, \& Cornell, 2005; Shroff, Deneen, \& Ng, 2011; Sivo \& Pan, 2005).

TAM provided associations between perceived usefulness (U), perceived ease of use (EOU), users' attitudes towards using (A), behavioural intentions to use (BI) and actual use of computer systems (Davis, 1986; Davis et al., 1989). TAM adopted the same assumptions of users' attitudes towards using (A) and BI from TRA. In addition, Davis (1989) further defined $U$ as how much an individual believes using a system improves job performance and perceived EOU as how much an individual believes a system is easy to use. $U$ is a major determinant of the user's intentions while EOU has a significant effect on the user's intentions.

\section{Extended TAM}

Researchers have found that resources are a key determinant towards learning and adopting information systems (Lee, 2008; Morris \& Venkatesh, 2010; Smith \& Sivo, 2012). Resources influence users' motivation in the information system. $\mathrm{R}$ is the individual's belief in personal and organisational resources that the person needs to use an information system. The concept of R first came from TPB (Ajzen, 1985). Mathieson, Peacock, and Chin (2001) argued that overlooking the resources barriers, such as lack of time, money, and equipment, might prevent an individual from using the technology. Mathieson et al. (2001) therefore proposed an extended TAM with the constant "perceived resources" (R). They defined R as the objective measurement of the belief in the resources towards a specific task at a single point of time. The results of the Mathieson et al. (2001) research indicate that R affects an individual's BI and EOU, and has a minor effect on U (Figure 1). 


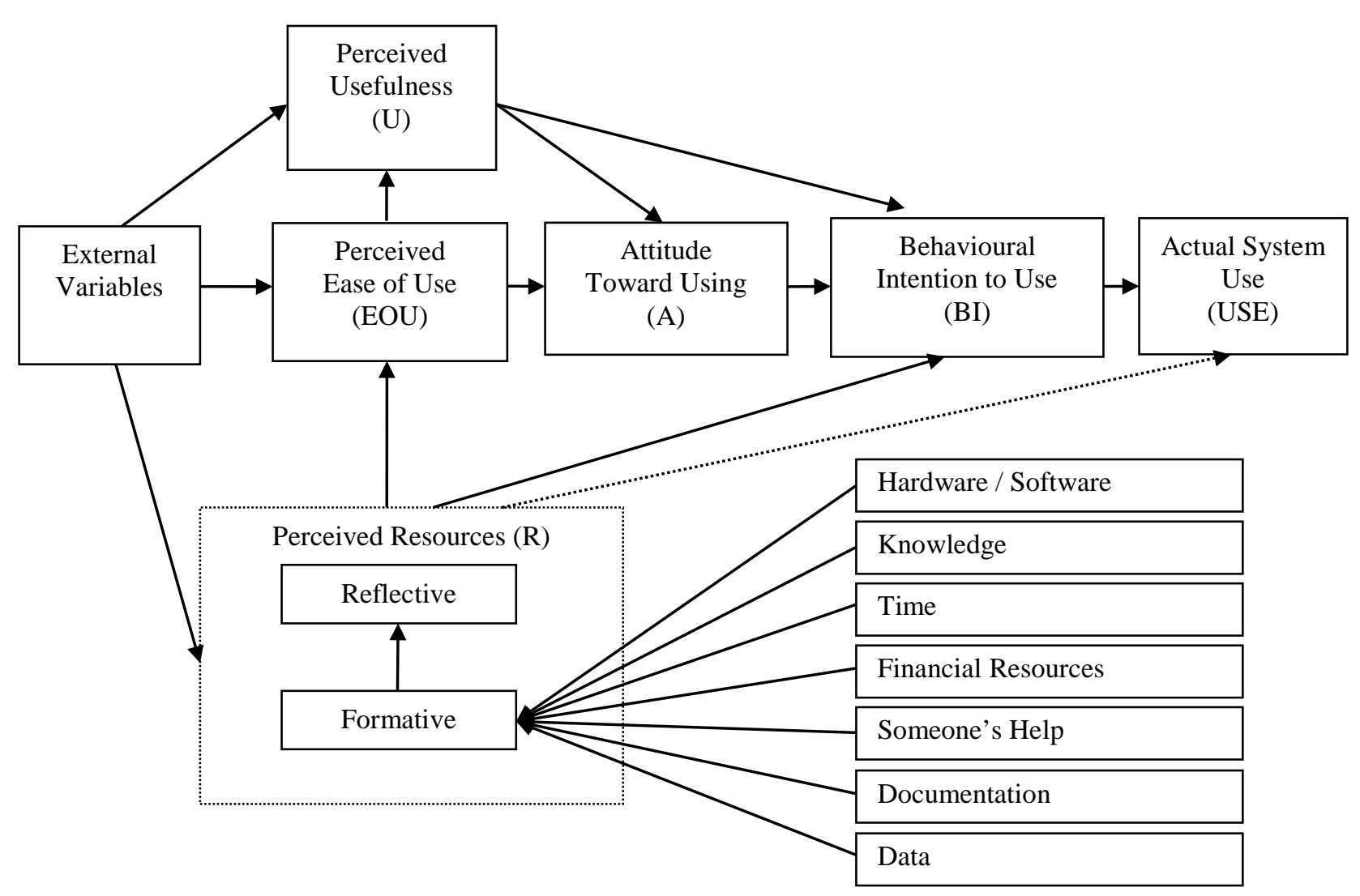

Figure 1. Derived in part from extended TAM (Mathieson et al., 2001, p. 92)

Lee (2008) conducted a study of 1,125 college students who used a web-based learning system in their universities to examine the influence of perceptions of needed resources towards students' adoption of an OLS. A model was proposed to denote internal and external organisational factors which represented R. The findings not only confirmed the constructs of the original TAM, but also suggested that $U$ and EOU influence $\mathrm{R}$ and that $\mathrm{R}$ could lead to better online adoption.

Based on a review of the literature, the following hypotheses $(\mathrm{H})$ were proposed:

- H1: Perceived resources will have a significant positive effect on perceived usefulness.

- H2: Perceived resources will have a significant positive effect on perceived ease of use.

- H3: Perceived resources will have a significant positive effect on behavioural intention.

- H4: Perceived ease of use will have a significant positive effect on perceived usefulness.

- H5: Perceived ease of use will have a significant positive effect on attitude towards using.

- H6: Perceived usefulness will have a significant positive effect on attitude towards using.

- H7: Perceived usefulness will have a significant positive effect on behavioural intention to use.

- H8: Attitude towards using will have a significant positive effect on behavioural intention to use.

- H9: Behavioural intention to use will have a significant positive effect on actual system use. 


\section{Methodology}

\section{Participants}

Data was collected from two survey questionnaires. The participants were students enrolled in WebCT online courses offered in the College of Education at a large public university located in the south-eastern part of the United States. The total enrolment in fall 2008 was 168 students in "Introduction to Educational Technology" and 84 students in "Foundation of Developmental Reading”.

\section{Study design}

This study utilised a pre-test, post-test experimental research design in which data was collected through surveys administered at two points in time to investigate the changes in students' beliefs, attitudes, intentions, and behaviours towards the use of WebCT. The participants were asked to complete the same identical questionnaire two times in a 6-week interval. The study focused on the relationships between six manifest variables - perceived usefulness (U), perceived ease of use, (EOU) perceived resources (R), attitude towards using (A), behavioural intentions to use (BI), and the actual system use (USE) of WebCT. The causal constructs were based on the belief-attitude-intention-behaviour relationships in TAM and were adapted in PRATAM (see Figure 2).

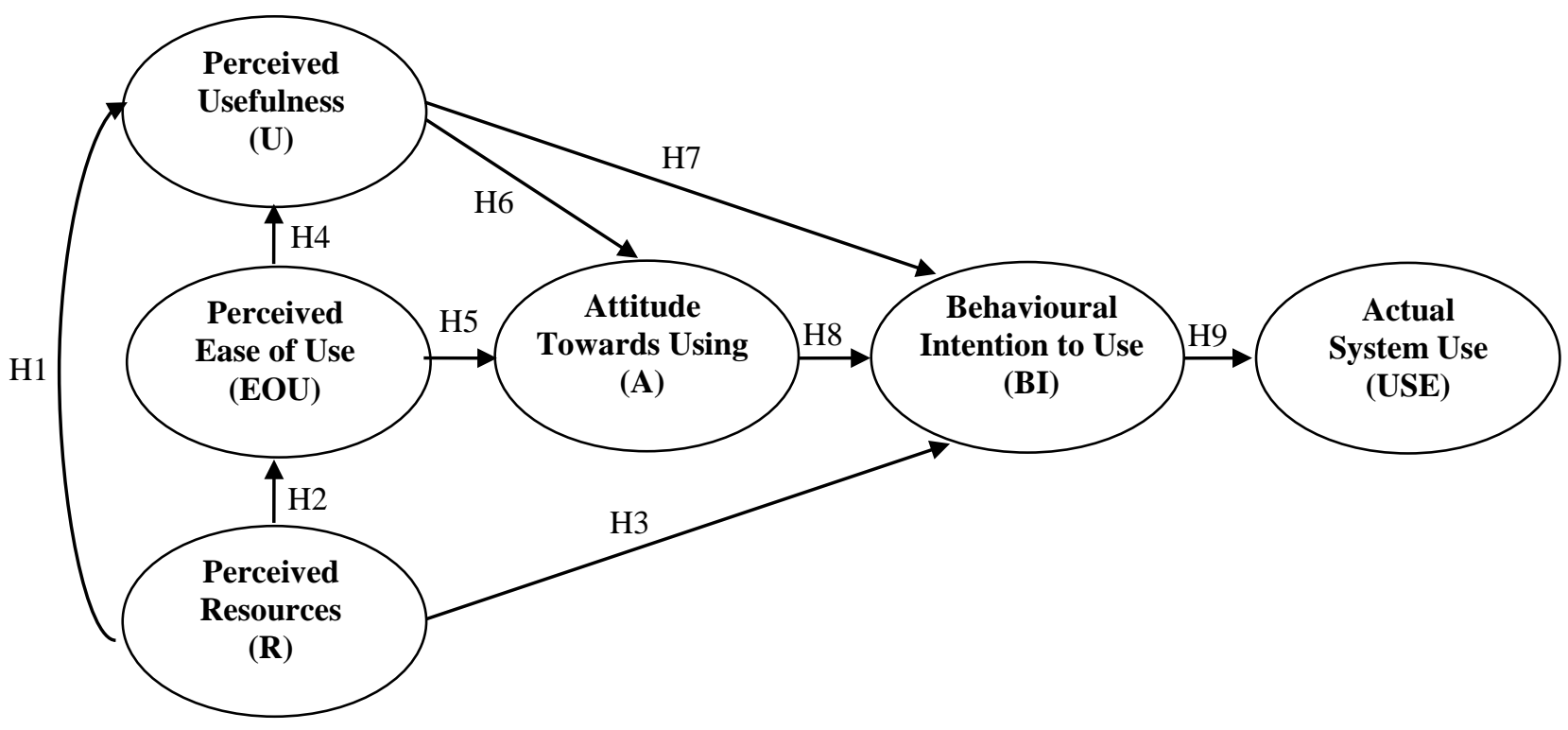

Figure 2. Hypothesis model of PRATAM

\section{Data analysis}

The data analyses in the current research consisted of two sections: (1) validity and reliability of the instruments and (2) structural equation modelling (SEM) on the model fit and weights of PRATAM constructs. A repeated-measures analysis of variance (ANOVA) was used to test the consistency between the pre-test and post-test data. The data analysis procedures were conducted via statistic software packages SPSS ${ }^{\circledR}$ for Windows ${ }^{\circledR}$ 17.0.1 and SAS ${ }^{\circledR}$ for Windows ${ }^{\circledR}$ 9.2. The standardised coefficient beta $(\beta)$ and the significant values were generated to analyse the weight and significance of the research hypotheses. The coefficient of determination $\left(\mathrm{R}^{2}\right)$ value and fit indexes were generated to inspect the manifest variables constructs and the overall goodness of fit for PRATAM. 


\section{Instruments}

The survey instruments were adopted from previous research studies (Lee, 2008; Pan, 2003; Siegel, 2008), which have shown reliability and validity evidence. A total of 30 question items were used in the questionnaire. All the items were a brief statement followed by a 7-point Likert scale ranging from extremely likely (7) to extremely unlikely (1) as well as not applicable (N/A). Table 1 provides the list of items used to measure each variable. The Cronbach's alpha reliability for the items of each construct has been reported for pre-test and post-test data and compared with the reliabilities reported in Mathieson, 2001, Pan (2003), and Siegel (2008) from which the items were adapted.

Table 1

List of items for each variable

\begin{tabular}{|c|c|}
\hline Variable & Item \\
\hline $\begin{array}{l}\text { Perceived resources }(\mathrm{R}) \\
\text { instrument }\end{array}$ & $\begin{array}{l}\text { I have the resources I would need to use WebCT in my course. } \\
\text { There are no barriers to my using WebCT in my course. } \\
\text { I would be able to use WebCT in my course if I wanted to. } \\
\text { I have access to the resources I would need to use WebCT in my course. }\end{array}$ \\
\hline $\begin{array}{l}\text { Perceived usefulness (U) } \\
\text { instrument }\end{array}$ & $\begin{array}{l}\text { Using WebCT in my class would enable me to accomplish tasks more quickly. } \\
\text { Using WebCT would improve my class performance. } \\
\text { Using WebCT in my class would increase my productivity. } \\
\text { Using WebCT would enhance my effectiveness in my course work. } \\
\text { Using WebCT would make it easier to do my course work. } \\
\text { I would find WebCT useful in my course work. }\end{array}$ \\
\hline $\begin{array}{l}\text { Perceived ease of use (EOU) } \\
\text { instrument }\end{array}$ & $\begin{array}{l}\text { Learning to use WebCT would be easy for me. } \\
\text { I would find it easy to get WebCT to do what I want it to do. } \\
\text { My interaction with WebCT would be clear. } \\
\text { I would find WebCT to be flexible to interact with. } \\
\text { It would be easy for me to become skillful at using WebCT. } \\
\text { I would find WebCT easy to use. }\end{array}$ \\
\hline $\begin{array}{l}\text { Attitude towards using (A) } \\
\text { instrument }\end{array}$ & $\begin{array}{l}\text { WebCT is beneficial. } \\
\text { WebCT is positive. } \\
\text { I would find WebCT easy to use. }\end{array}$ \\
\hline $\begin{array}{l}\text { Behavioural intention to use } \\
\text { (BI) instrument }\end{array}$ & $\begin{array}{l}\text { Assuming I have access to WebCT, I intend to use it. } \\
\text { Given that I have access to WebCT, I plan to use it. } \\
\text { It is worth it to use WebCT. } \\
\text { I will frequently use WebCT in the future. }\end{array}$ \\
\hline $\begin{array}{l}\text { Actual use behaviour (USE) } \\
\text { instrument }\end{array}$ & $\begin{array}{l}\text { On the average, the frequency I log in on WebCT: } \\
\text { On the average, the length of time I spent every time I log in on WebCT: }\end{array}$ \\
\hline
\end{tabular}

- $\quad$ Perceived resources (R) instrument: Four items were adapted from Mathieson et al. (2001).

- $\quad$ Perceived usefulness (U) instrument: Six items were adapted from Pan (2003).

- $\quad$ Perceived ease of use (EOU) instrument: Six items were adapted from Pan (2003).

- $\quad$ Attitude towards using (A) instrument: Three items were adapted from Siegel (2008).

- $\quad$ Behavioural intention to use (BI) instrument: Four items were adapted from Lee (2008).

- Actual system use (U) instrument: The data of actual system use of WebCT in the current study was collected by frequency of use and amount of time spent. Pan (2003) applied these concepts in the instruments and successfully represented students' WebCT usage. Two items measured actual system use (U). Both items were measured on a 6x-point nominal scale. The items are "On the average, the frequency I log in on WebCT:” and "On the average, the length of time I spent every time I login on WebCT:”. 
- Demographics: Five items were used to collect demographics information. Items were adapted from Pan's (2003) and Siegel's (2008) instruments to evaluate students' basic demographic information. The items included gender, age, racial/ethnic groups, academics status and occupational status.

\section{Results}

\section{Demographic results}

A total of 115 valid pre-test post-test survey questionnaires were used to analyse the data. The response rate was $54.6 \%$ and $30.9 \%$ for the two online classes. The overall response rate for both online classes was $46.6 \%$. Females represented $89.6 \%(n=103)$ of the total participants, while males, $10.4 \%(n=12)$. The age of the participants ranged from 18 to 52 years with the average age being 23 years for both males and females; data from two participants were missing. Most of the participants were White (93\%), with Hispanic (8.7\%), Black (3.5\%), and Asians (1.7\%). Five participants did not respond to this question, and data from one participant was missing. Sophomores (43.5\%), juniors (27.8\%) and graduate students (18.3\%) constituted the top three groups in academic status. Approximately $42 \%$ of the students had part-time jobs followed by $34 \%$ having no current job, and $27 \%$ having full-time jobs.

\section{Validity results}

An exploratory factory analysis (EFA) was first conducted to validate the structures and the measurement items for R and PRATAM. A total of 25 measurement items (4 items for R, 6 items for U, 6 items for EOU, 3 items for A, 4 items for BI and 2 items for U) were analysed through SPSS 17's dimension reduction function on both pre-test and post-test data after excluding the demographic instruments. Table 2 displays the results of Kaiser-Meyer-Olkin (KMO) measure of sampling adequacy and Bartlett's test of sphericity tests from pre-test and post-test data.

Table 2

KMO and Bartlett's test for pre-test data

\begin{tabular}{lcc}
\hline & Pre-test & Post-test \\
\hline Kaiser-Meyer-Olkin measure of sampling adequacy & .875 & .916 \\
Bartlett's test of sphericity & & \\
Approx. chi-square & 2773.763 & 2981.211 \\
Df & 300 & 300 \\
Sig. & .000 & .000 \\
\hline
\end{tabular}

KMO sampling adequacy test in the pre-test (.875) and the post-test (.916) reveals a meritorious (range from 0.80 to 0.89 ) and a marvellous (range from 0.90 to 1.00 ) compact pattern of correlations respectively (Kaiser, 1974). These results suggest that factor analysis could be assumed to provide distinct and reliable factors (Field, 2005). In addition, Bartlett's test of sphericity for both the pre-test and post-test results (sig. < .05) suggested factor analysis was suitable for the study (Field, 2005). Based on the assumptions of the causal relationships between the manifest variables, the Promax rotation method (Hendrickson \& White, 1964) was used. Table 3 displays the results of EFA for pre-test data. 
Table 3

Rotated factor component matrix for pre-test data

\begin{tabular}{|c|c|c|c|c|c|}
\hline & & & & & \\
\hline & $\overline{1}$ & 2 & 3 & 4 & 5 \\
\hline R1 & & & & .850 & \\
\hline R2 & & & & .886 & \\
\hline R3 & & & & .791 & \\
\hline R4 & & & & .669 & \\
\hline U1 & & & .958 & & \\
\hline U2 & & & .835 & & \\
\hline U3 & & & .887 & & \\
\hline U4 & & & .947 & & \\
\hline U5 & & & .742 & & \\
\hline U6 & & & .668 & & \\
\hline EOU1 & & .946 & & & \\
\hline EOU2 & & .893 & & & \\
\hline EOU3 & & .946 & & & \\
\hline EOU4 & & .845 & & & \\
\hline EOU5 & & .829 & & & \\
\hline EOU6 & & .909 & & & \\
\hline A1 & .693 & & & & \\
\hline A2 & .855 & & & & \\
\hline A3 & .966 & & & & \\
\hline BI1 & .702 & & & & \\
\hline BI2 & .800 & & & & \\
\hline BI3 & .894 & & & & \\
\hline BI4 & .821 & & & & \\
\hline USE1 & & & & & -.498 \\
\hline USE2 & & & & & .896 \\
\hline
\end{tabular}

Note: Extraction method: Principal component analysis. Rotation method: Promax with Kaiser normalisation.

The pre-test factor component matrix indicates that the initial instrument items provided adequate measurements on the manifest variables such as R (R1, R2, R3, R4), U (U1, U2, U3, U4, U5, U6), EOU (EOU1, EOU2, EOU3, EOU4, EOU5, EOU6), and actual system use (USE1, USE2). However, the manifest variables (attitude towards using - A1, A2, A3 - and behavioural intention to use - BI1, BI2, BI3, BI4) fell into the same factor. These results suggest that the measurement items for A and BI might be interrelated.

The post-test factor component matrix also indicates that the measurement items for R (R1_PST, R2_PST, R3_PST, R4_PST), EOU (EOU1_PST, EOU2_PST, EOU3_PST, EOU4_PST, EOU5_PST, EOU6_PST), and USE (USE1_PST, USE2_PST) demonstrate adequate independence with their own group of factors. However, a problem was raised on the measurement items for U (i.e., U1_PST, U2_PST, U3_PST, U4_PST, U5_PST, U6_PST), A (i.e., A1_PST, A2_PST, A3_PST), and BI (i.e., BI1_PST, BI2_PST, BI3_PST, BI4_PST). These three manifest variables fell into the same factor, which failed to support the independence 
between the manifest variables (Table 4). While recognising the issues on the interrelated measurement items for some manifest variables, the current research, however, still used the initial measurement items for all six manifest variables to maintain the same construct of PRATAM throughout the whole study.

Table 4

Rotated factor component matrix for post-test data

\begin{tabular}{llllll}
\hline & Factor 1 & Factor 2 & Factor 3 & Factor 4 & Factor 5 \\
\hline R1_PST & & & .890 & & \\
R2_PST & & & .995 & & \\
R3_PST & & & .758 & \\
R4_PST & & & .932 & \\
U1_PST & .918 & & \\
U2_PST & .995 & & & \\
U3_PST & .994 & & & \\
U4_PST & 1.014 & & & \\
U5_PST & .960 & & & \\
U6_PST & .800 & & & \\
EOU1_PST & & .530 & & \\
EOU2_PST & & .658 & & \\
EOU3_PST & & .630 & & \\
EOU4_PST & & .655 & & \\
EOU5_PST & & 1.092 & & \\
EOU6_PST & & 1.027 & & \\
A1_PST & .816 & & & \\
A2_PST & .816 & .008 & \\
A3_PST & .698 & .624 & & & \\
BI1_PST & .624 & & \\
BI2_PST & .691 & & & \\
BI3_PST & .669 & & & \\
BI4_PST & .699 & & & \\
USE1_PST & & & & \\
USE2_PST & & & & \\
\hline
\end{tabular}

\section{Reliability results}

The values of six manifest variables were summed from its measurement items. Reliability analysis was conducted to validate the internal consistency on the five sets of measurement items. The measurement items were inspected on the same dimension as their manifest variables. The only exception was the measurement items for USE, which measured the two different dimensions (i.e., frequency and length) of WebCT usage. Table 5 displays Cronbach's alpha (Cronbach, 1951) for the five manifest variables on both pre-test and posttest data. Carmines and Zeller (1979) suggested Cronbach's alpha over 0.70 is considered acceptable reliability. Most measurement sets exceeded the 0.9 level except $\mathrm{R}$, which indicates good internal consistency on the test results. 
Table 5

Cronbach's reliability analysis

\begin{tabular}{llll}
\hline & Pre-test & Post-test & Original article \\
\hline Perceived resources (R1-R4) & .818 & .908 & 0.92 \\
Perceived usefulness (U1-U6) & .951 & .956 & $0.91-0.95$ \\
Perceived ease of use (EOU1-EOU6) & .956 & .922 & $0.94-0.95$ \\
Attitude towards using (A1-A3) & .945 & .953 & 0.99 \\
Behavioural intention to use (BI1-BI4) & .914 & .961 & 0.81 \\
\hline
\end{tabular}

\section{Repeated-measures ANOVA results}

In order to identify the differences on students' pre-test and post-test scores within PRATAM's six manifest variables, repeated-measures ANOVA was used to test the assumption of the homogeneity of variance. The results show that the mean score of $\mathrm{R}$ in the pre-test $(M=25.87)$ was not significantly different from the mean score in the post-test $(M=25.59), F(1,111)=.844, p<.05$. Therefore, the results suggest that none of the scores for PRATAM's manifest variables was significantly different between pre-test and post-test data (Table 6).

Table 6

Test of repeated-measures analysis of variance (ANOVA)

\begin{tabular}{lllll}
\hline & Pre-test* & Post-test* $^{*}$ & F & Significance \\
\hline Perceived resources (R1-R4) & 25.87 & 25.59 & .844 & .36 \\
Perceived usefulness (U1-U6) & 32.86 & 33.93 & 3.380 & .07 \\
Perceived ease of use (EOU1-EOU6) & 36.31 & 36.82 & .930 & .34 \\
Attitude towards using (A1-A3) & 18.45 & 18.43 & .004 & .95 \\
Behavioural intention to use (BI1-BI4) & 24.68 & 24.74 & .031 & .86 \\
Actual system use (USE1-USE2) & 9.01 & 8.86 & 2.039 & .16 \\
\hline
\end{tabular}

Note: *Means

\section{Path analysis results for pre-test data}

Path analysis was used to examine the causal relationships between the manifest variables of PRATAM. SAS Windows 9.2 PROC CALIS (i.e., covariance analysis of linear structural equations) procedure was utilised to perform the analysis of covariance matrices. Maximum likelihood parameter estimation method was used. The equations with standardised coefficients of the PRATAM in pre-test data are presented in Table 7 and Figure 3.

Table 7

Equations with standardised coefficients of PRATAM in pre-test data

\begin{tabular}{|c|c|c|c|c|c|c|c|c|c|}
\hline $\mathrm{U}$ & $=$ & $0.262 * *$ & EOU & $+0.208^{*}$ & $\mathrm{R}$ & +0.922 & E1 & & \\
\hline EOU & $=$ & $0.347 * * *$ & $\mathrm{R}$ & +0.938 & E2 & & & & \\
\hline A & $=$ & $0.624^{* * *}$ & $\mathrm{U}$ & $+0.224 * *$ & EOU & +0.684 & E3 & & \\
\hline BI & $=$ & $0.202 * *$ & $\mathrm{U}$ & $+0.663 * * *$ & A & +0.024 & $\mathrm{R}$ & +0.566 & E4 \\
\hline USE & $=$ & 0.169 & $\mathrm{BI}$ & +0.986 & E5 & & & & \\
\hline
\end{tabular}

Note: R: perceived resources; U: perceived usefulness; EOU: perceived ease of use; A: attitude towards using; BI: behavioural intention to use; USE: actual system use; *t>1.96 $(p<.05)$; **t $>2.58(p<.01)$; ***t> $3.30(p<.001)$ 


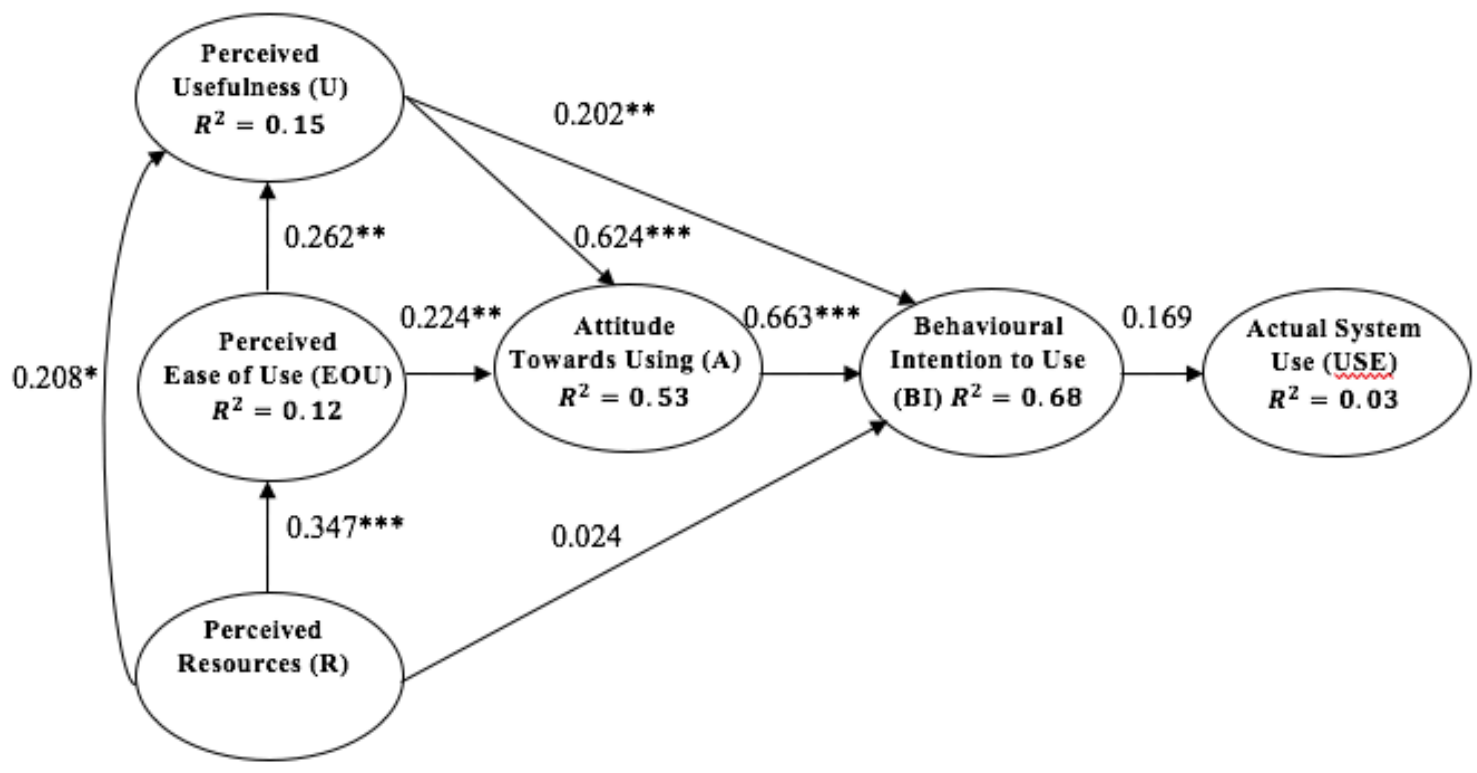

$* t>1.96(p<.05) ;{ }^{* *} t>2.58(p<.01) ;{ }^{* * *} t>3.30(p<.001)$; ${ }^{* *} t>2.58(p<.01)$; *** $t>3.30$ (the level of $p<.001$ )

Figure 3. Path diagram of PRATAM in pre-test data

Hatcher (1994) suggested the path coefficient $t$ value should exceed 1.96 at the $p<.05$ level, exceed 2.58 at the $p<.01$ level, and exceed 3.30 at the $p<.001$ level. The $\mathrm{R}^{2}$ values indicate that $\mathrm{R}$ accounted for $12 \%$ of the variance of EOU; R and EOU accounted for $15 \%$ of the variance of $\mathrm{U}$; $\mathrm{U}$ and EOU accounted for $53 \%$ of the variance of $\mathrm{A}$; and $\mathrm{R}, \mathrm{U}$, and $\mathrm{A}$ accounted for $68 \%$ of the variance of BI to use. However, BI accounted for only $3 \%$ of the variance of USE.

The fit indices were consulted to determine the overall fit of the proposed model to the data. A value lower than 0.08 for root mean square error of approximation (RMSEA) indicates good model fit while other values require 0.95 or larger to indicate an acceptable model fit (Fan \& Sivo, 2007; Hu \& Bentler, 1999; Sivo, Fan, Witta, \& Willse, 2006). The values of comparative fit index (CFI) (0.96), normed fit index (NFI) (0.93), and McDonald's centrality (MC) (0.95) were within acceptable range. However, the values of chi-square (17.2) and RMSEA (0.13) were high suggesting misfit between the proposed PRATAM and the pre-test data. The fit indexes indicate that the model deserves modification for better data fit.

The examination of residual matrix and Wald modification beta matrix indicated that a path between perceived EOU and the BI is warranted to significantly decrease the chi-square value. Therefore, a causal link from perceived EOU to BI was added in PRATAM. The equations with standardised coefficients of the revised PRATAM in pre-test data are presented in Table 8 and Figure 4 . The $\mathrm{R}^{2}$ remained the same after adding the new causal relationship between perceived EOU to BI. The only exception was BI, which accounted for $4 \%$ more variance in addition to $72 \%$ of the variance by the new causal relationships from perceived EOU. The fit indexes obtained from the revised PRATAM indicated that the modified PRATAM fitted better with the pre-test data when compared to the initial model. The value of RMSEA was close to 0 indicating negligible difference between the revised PRATAM model and the data. In addition, the chi-square value significantly decreased to 4.67 indicating a good fit. Furthermore, NFI, CFI and MC all exceeded the 0.95 level, providing further evidence of a good fit. 
Table 8

Equations with standardised coefficients of revised PRATAM in pre-test data

\begin{tabular}{lllllllllll}
\hline $\mathrm{U}$ & $=0.262^{* *}$ & $\mathrm{EOU}$ & $+0.208^{*}$ & $\mathrm{R}$ & +0.922 & $\mathrm{E} 1$ & & & & \\
$\mathrm{EOU}$ & $=0.347^{* * *}$ & $\mathrm{R}$ & +0.938 & $\mathrm{E} 2$ & & & & & \\
$\mathrm{~A}$ & $=0.624^{* * *}$ & $\mathrm{U}$ & $+0.224^{* *}$ & $\mathrm{EOU}$ & +0.684 & $\mathrm{E} 3$ & & & \\
$\mathrm{BI}$ & $=0.197^{* *}$ & $\mathrm{U}$ & $+0.588^{* * *}$ & $\mathrm{~A}$ & -0.027 & $\mathrm{R}$ & $+0.215^{* * *}$ & $\mathrm{EOU}$ & +0.533 & $\mathrm{E} 4$ \\
$\mathrm{USE}$ & $=0.170$ & $\mathrm{BI}$ & +0.986 & $\mathrm{E} 5$ & & & & & & \\
\hline
\end{tabular}

Note: ${ }^{*} t>1.96(p<.05) ;{ }^{* *} t>2.58(p<.01) ;{ }^{* * *} t>3.30(p<.001)$

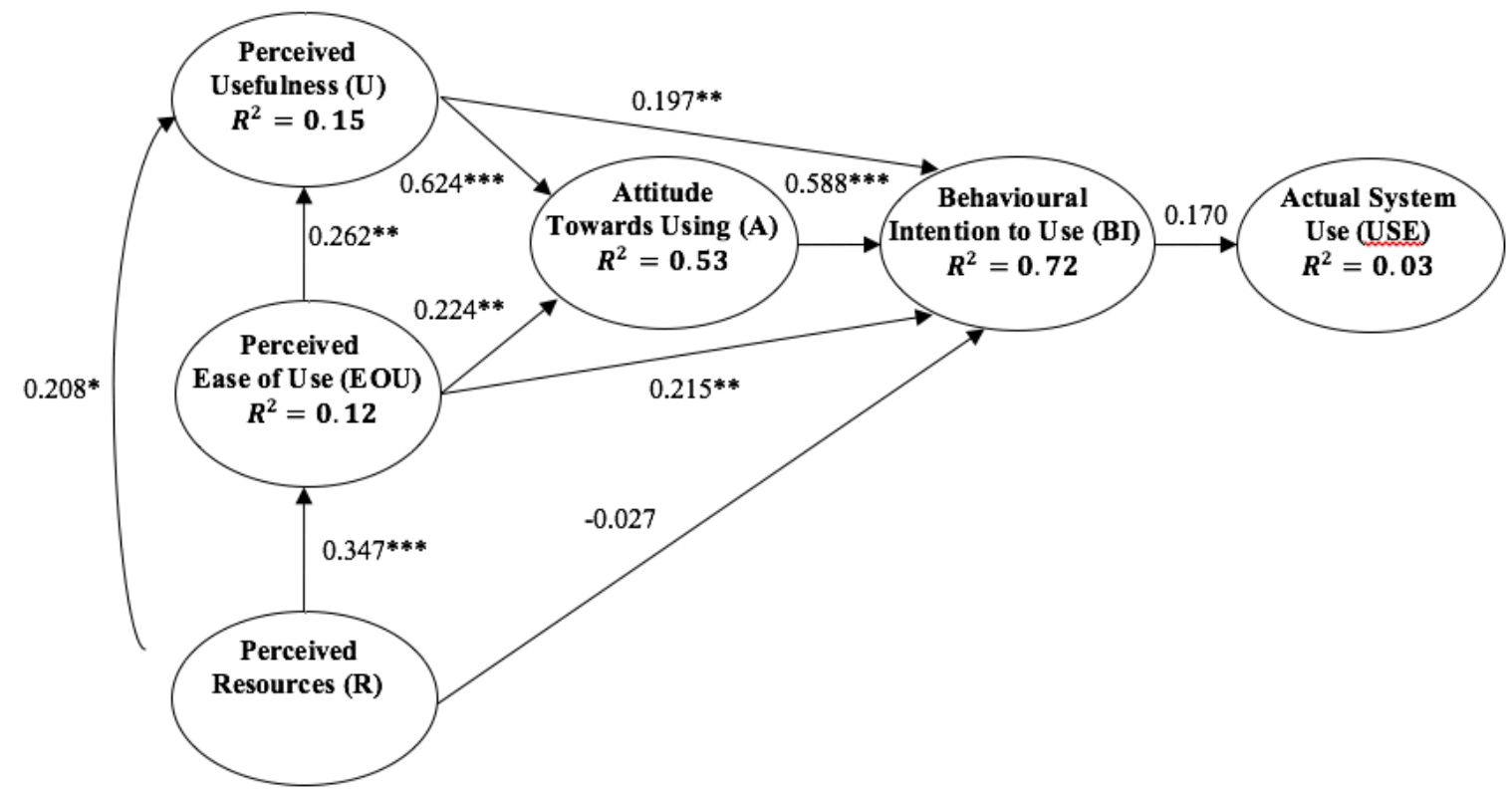

$* t>1.96(p<.05) ; * * t>2.58(p<.01) ; * * * t>3.30(p<.001)$

Figure 4. Path diagram of revised PRATAM in pre-test data

\section{Path analysis results for post-test data}

The equations with standardised coefficients of PRATAM in pre-test data are presented in Table 9 and Figure 5. The $\mathrm{R}^{2}$ values indicate that $\mathrm{R}$ accounted for $32 \%$ of the variance of EOU, and $\mathrm{R}$ and EOU accounted for $30 \%$ of the variance of U. U and EOU also accounted for $72 \%$ of the variance of A. R, U and A accounted for $77 \%$ of the variance of BI. However, BI accounted for only $27 \%$ of the variance of U. Examination of the fit indexes indicated a good fit of PRATAM to the post-test data. The values of chi-square, RMSEA, CFI, NFI, and MC were 2.38, 0.00, 1.00, 0.99 and 1.00 respectively. The residual matrix did not have high values, thereby providing further evidence of a good fit model. 
Table 9

Equations with standardised coefficients of PRATAM in post-test data

\begin{tabular}{llllllllll}
\hline $\mathrm{U}$ & $=$ & $0.448^{* * *}$ & $\mathrm{EOU}$ & +0.107 & $\mathrm{R}$ & +0.834 & $\mathrm{E} 1$ & & \\
$\mathrm{EOU}$ & $=$ & $0.564^{* * *}$ & $\mathrm{R}$ & +0.826 & $\mathrm{E} 2$ & & & & \\
$\mathrm{~A}$ & $=$ & $0.745^{* * *}$ & $\mathrm{U}$ & $+0.168^{* *}$ & $\mathrm{EOU}$ & +0.530 & $\mathrm{E} 3$ & & \\
$\mathrm{BI}$ & $=$ & $0.218^{* *}$ & $\mathrm{U}$ & $+0.654^{* * *}$ & $\mathrm{~A}$ & +0.082 & $\mathrm{R}$ & +0.474 & $\mathrm{E} 4$ \\
$\mathrm{USE}$ & $=0.274^{* *}$ & $\mathrm{BI}$ & +0.962 & $\mathrm{E} 5$ & & & & \\
\hline Note: ${ }^{* *} t>1.96(p<.05) ; * *$ & & & & & & \\
\end{tabular}

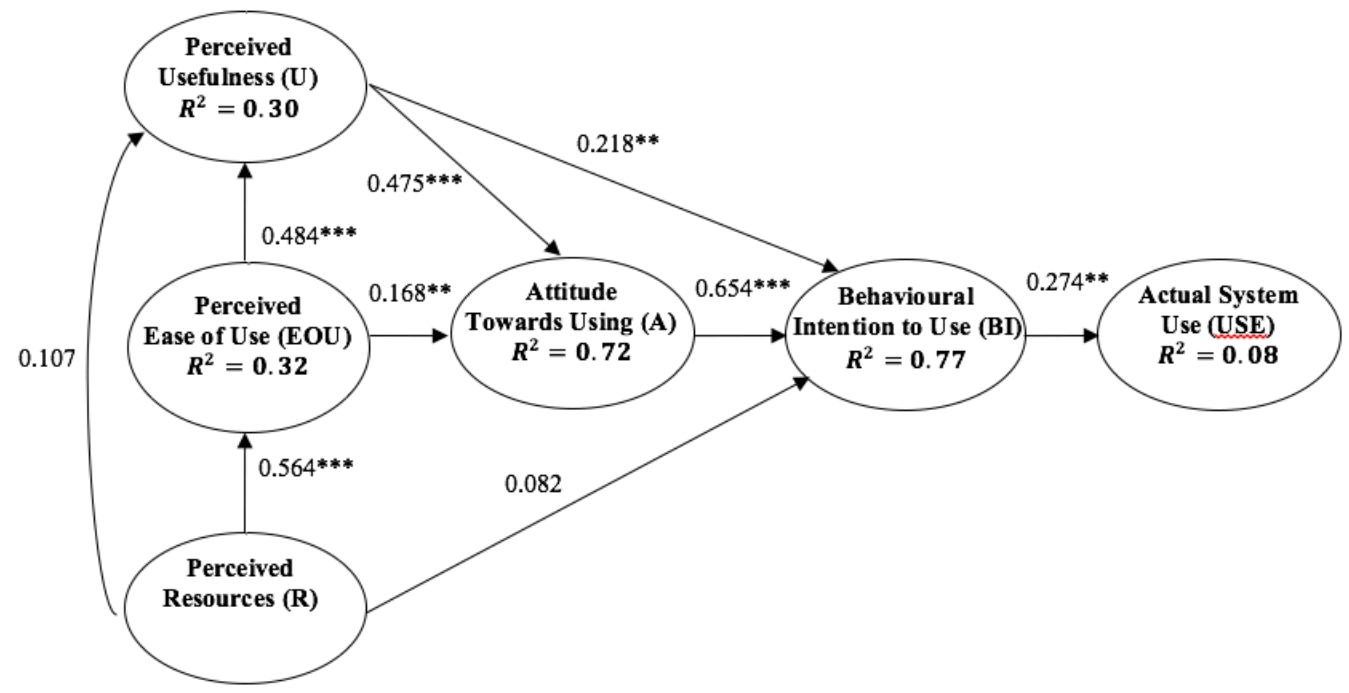

$* t>1.96(p<.05) ; * * t>2.58(p<.01) ; * * * t>3.30(p<.001)$

Figure 5. Path diagram of PRATAM in post-test data

\section{Hypotheses-testing results}

The examination of path coefficients in both the pre-test and post-test models provide full support for hypotheses 2, 4, 5, 6, 7 and 8, partial support for hypotheses 1 and 9, and no support for hypothesis 3 (Table 10).

Table 10

Summary of hypotheses testing results

\begin{tabular}{llllllll}
\hline Hypothesis & Pre-test $^{*}$ & Significance & Revised $^{*}$ & Significance & Post-test* & Significance & Result \\
\hline H1 & 0.208 & $p<0.05$ & & & 0.107 & $p>0.05$ & $\mathrm{P}$ \\
H2 & 0.347 & $p<0.05$ & & & 0.564 & $p<0.05$ & $\mathrm{~F}$ \\
H3 & 0.024 & $p>0.05$ & -0.027 & $p>0.05$ & 0.082 & $p>0.05$ & $\mathrm{~N}$ \\
H4 & 0.262 & $p<0.05$ & 0.448 & $p<0.05$ & 0.262 & $p<0.05$ & $\mathrm{~F}$ \\
H5 & 0.224 & $p<0.05$ & 0.224 & $p<0.05$ & 0.168 & $p<0.05$ & $\mathrm{~F}$ \\
H6 & 0.624 & $p<0.05$ & 0.624 & $p<0.05$ & 0.475 & $p<0.05$ & $\mathrm{~F}$ \\
H7 & 0.202 & $p<0.05$ & 0.197 & $p<0.05$ & 0.218 & $p<0.05$ & $\mathrm{~F}$ \\
H8 & 0.663 & $p<0.05$ & 0.588 & $p<0.05$ & 0.654 & $p<0.05$ & $\mathrm{~F}$ \\
H9 & 0.169 & $p<0.05$ & 0.170 & $p<0.05$ & 0.274 & $p<0.05$ & $\mathrm{~F}$ \\
\hline
\end{tabular}

Note: *Represents regression coefficients; F = full support; $\mathrm{P}=$ partial support; $\mathrm{N}=$ no support 


\section{Discussion}

The purpose of this study was to identify the factors and causal relationships that influence students' WebCT usage behaviours, by utilising PRATAM. Overall, PRATAM demonstrated a significant fit to the collected data and explained the constructs and causal relationships from the aspects of students' beliefs, attitudes, intentions and behaviours. In the pre-test data, PRATAM missed several fit indexes' cut-off levels and chisquare $\left(\chi^{2}=17.19 p<.01\right)$ failed to support a goodness of fit for PRATAM. However, a revised additional causal relationship from EOU to BI showed a moderate model fit with chi-square $\left(\chi^{2}=4.67, p>.05\right)$. On the other hand, the post-test data showed a great model fit with $\left(\chi^{2}=2.38, p>.05\right)$ PRATAM without any modification. A possible reason for the need to modify PRATAM in the pre-test might be the time required to form the BI on using WebCT.

Davis et al. (1989) suggested that the formation of the BI requires a period of time. Even the initial design of the current research arranged the pre-test in the middle of the semester so that students had time to form the BI. This period of time might not be adequate for students to respond to the instrument. The higher fit indexes result in the post-test data indicated that students' BI was well developed at the time of the post-test. Thus, the result suggests that formation of BI on using WebCT might require as long as a whole semester.

Overall, PRATAM explained more variance in the post-test data than the pre-test data in this study. Compared to the pre-test data, $\mathrm{R}^{2}$ gained $5 \%$ to $20 \%$ in the post-test data. Therefore, the results indicate that students' progress in a WebCT course might influence the abilities of PRATAM to interpret the students' beliefs, attitudes, intentions, and behaviours. Table 11 lists the comparison of $\mathrm{R}^{2}$ values in the pre-test, posttest with revised PRATAM, post-test conditions and the results posted by Mathieson et al. (2001). The $\mathrm{R}^{2}$ values generated in this study show a similar pattern when compared to the $\mathrm{R}^{2}$ values in the Mathieson et al. (2001) study. However, some exceptions in the results still need to be recognised.

Table 11

Comparison of $R^{2}$ values

\begin{tabular}{|c|c|c|c|c|}
\hline & \multicolumn{2}{|c|}{ Pre-test } & \multirow[t]{2}{*}{ Post-test } & \multirow{2}{*}{$\begin{array}{l}\text { Mathieson } \\
\text { et al. (2001) }\end{array}$} \\
\hline & Original & Revised & & \\
\hline Perceived usefulness (U) & 0.15 & 0.15 & 0.30 & 0.22 \\
\hline Perceived ease of use (EOU) & 0.12 & 0.12 & 0.32 & 0.26 \\
\hline Attitude towards using (A) & 0.53 & 0.53 & 0.72 & 0.67 \\
\hline Behavioural intention to use (BI) & 0.68 & 0.72 & 0.77 & 0.40 \\
\hline Actual system use (USE) & 0.03 & 0.03 & 0.08 & 0.30 \\
\hline
\end{tabular}

The study provided full support for hypotheses 2, 4, 5, 6, 7 and 8, partial support for hypotheses 1 and 9, and no support for hypothesis 3 . Hypothesis 1 assumed that personal and organisational resources which students believe they could have for using WebCT will positively influence their beliefs on using the WebCT system and could improve their performance in the courses. The results for hypotheses 1 are consistent with the study conducted by Mathieson et al. (2001) in which the effect on $\mathrm{U}$ from $\mathrm{R}$ was also small $(\beta=0.216, p<.05)$. One reason for the partial support for hypothesis 1 might be that students with more resources could also have more knowledge of the capabilities and applications of WebCT, which makes those students also think WebCT is useful. On the other hand, students' attitudes towards using WebCT could also influence their beliefs. PRATAM proposed attitude towards using WebCT as the exogenous variables linked to both R and U. Hence, a student's positive attitude towards using WebCT could encourage him/her to pursue more resources; while this positive attitude also helps the student to believe WebCT is useful. Cheng, Lou, Kuo, and Shih (2013) examined students' acceptance of technology in digital game-based learning by measuring students' EOU, U, and user intentions through a survey. Results of the path analysis model were similar to those in the current study. Students' positive attitudes towards use and $U$ had a direct effect on their 
acceptance towards the game-based learning. Sánchez, Hueros, and Ordaz (2013) investigated acceptance and usage of WebCT using TAM among business and education sciences students. The results indicate that WebCT acceptance and usage were directly influenced by $U$ and indirectly by EOU. In the current study, EOU directly impacted $\mathrm{U}$, and attitude towards using WebCT and $\mathrm{U}$ indirectly influenced $\mathrm{BI}$ and $\mathrm{U}$, which was similar to Sánchez et. al’s (2013) study.

The results for hypothesis 3 are inconsistent with the findings from the study conducted by Mathieson et al. (2001), which demonstrated a significant relationship $(\beta=0.291, p<.05)$ on $\mathrm{R}$ to BI. As this current research used a conservative manner to duplicate Mathieson et al.'s (2001) extended TAM, the insignificant results on the relationship between $\mathrm{R}$ and $\mathrm{BI}$ are understandable. A further investigation on the relationships between $\mathrm{R}$ and $\mathrm{BI}$ in a higher education OLS setup is needed to clarify this issue.

The results of hypothesis 9 are not consistent with Davis et al.'s (1989) study ( $\beta=0.35, p<.001$ in time 1 and $\beta=0.63, p<.001$ in time 2$)$ and Mathieson et al.'s $(2001)$ study $(\beta=0.466, p<.05)$. One possible reason for the insignificant result in the pre-test data could be the formation of behavioural intention. The current research only found the significant result from the post-test data $(\beta=0.274, p<.05)$. The path coefficient values in both pre-test $(\beta=0.169, p>.05)$ and pre-test with the revised PRATAM $(\beta=0.170, p>.05)$ failed to conclude significant influences on USE from BI. One possible reason for the insignificant result in the pretest data could be the formation of BI. The students in the current study's pre-test assessment might not have had the proper time to form the completed BI. Therefore, BI in the pre-test data failed to display a significant path to actual system use. Furthermore, the EFA results are highly interrelated measurement scores in attitude towards and BI in the pre-test data. These interrelated results further support the thought that the students' BI in the pre-test was incomplete. Shroff, Deneen, and Ng (2011) utilised TAM by examining students' BI towards the utilisation of an e-portfolio system. Students' U, EOU, A, and BI were measured. The results of the present study are consistent with Shroff et al.'s (2011) study where students' EOU significantly influenced A. However, in the current study R had the strongest influence on U, which contrasts with Shroff et al.'s study, where EOU had the most influence on U.

\section{Contributions}

This study provides additional information regarding the usage behaviour of WebCT through TAM. We incorporated $\mathrm{R}$ as the alternative belief predictor to assess the usage behaviour of WebCT in higher education. While researchers (e.g., Lee, 2008) have adopted formative R into OLS, the overall reflective R have not been adopted into the WebCT system yet. An evaluation of students' overall perception of resources in higher education WebCT courses could help in understanding the issue of resources for school administrators, instructional designers, and researchers.

We utilised a pre-test, post-test design to evaluate the revised PRATAM where students' scores on the variables of interest (Figure 1) were examined before and after using WebCT. The influence of R on EOU and $\mathrm{BI}$, the impact of EOU on U and A, the influence of U and A on BI, and the effect of BI on USE increased from pre-test to post-test. These fluctuations suggest that students' initial beliefs, attitudes, intentions, and behaviours changed during the progress of the WebCT courses. Davis et al. (1989) also found the changes on the standardised coefficient beta over time. The students in the sample might have faced issues/barriers in using WebCT resources, which could have impacted their class performance and productivity. This might have decreased the impact of R on U after using WebCT. Issues in WebCT could have decreased students' perceptions of EOU (as they might have had to put extra effort into navigating through WebCT resources) and $\mathrm{U}$ of WebCT, which could have weakened the impact on their attitude towards using WebCT from pre-test to post-test scores. The findings from the present study could lead to the further development of effective strategies and pedagogies for supporting and locating resources to enhance the usage behaviour in an OLS. 


\section{Limitations}

The study has a few limitations. First, a convenience sample was used to collect data from two online classes. Hence, participants would be considered as biased and might not be representative of other groups or populations. Second, the response rate accounted for only $47 \%$ of the target population. Researchers have suggested that surveys with a lower response rate yield a more accurate measurement than surveys with a high response rate (Visser, Krosnick, Marquette, \& Curtin, 1996). The total valid sample in this study accounted for only 115 students, where Hatcher (1994) suggested an acceptable sample for more than 150 observations in SEM. Hence, sample size and response rate might bring biases to the results. Third, different OLS components and functions might result in different rates of WebCT usage. Therefore, WebCT usage may not represent comparable data over different course content and instructors. Fourth, we did not distinguish between reflective resources that measure overall perception of resource availability, and formative resources that measure specific factors such as technical expertise, hardware, software, and financial support for system utilisation (Mathieson et al., 2001).

\section{Conclusion and future research}

This paper introduced an overall reflective resource measurement of $\mathrm{R}$ in the TAM as a new aspect of students' beliefs into a higher education WebCT OLS and validated the influences towards other existing beliefs, attitudes, intentions, and behaviour variables. The results indicate that a small portion of $U$ and EOU was explained within PRATAM, suggestng the existence of external variables. Although Davis et al. (1989) suggested the influence of external variables in the original TAM, a similar finding has been made in a WebCT environment by Pan (2003), which found students' EOU and U were influenced by extraneous variables such as computer self-efficacy and subjective norms.

The instruments used in the current research to assess students' actual system use were based on the selfreported design. Additional studies that address actual system use in both self-reported and computerrecorded usage will bring more understanding to the students' actual usage behaviour towards WebCT. The current research assessed only $\mathrm{R}$ based on the reflective measures. Further investigation on formative resources would help to find out the potential leverage points for students' usage behaviours towards WebCT or other OLSs. We found variations in the causal relationships of PRATAM's variables at two different assessment times. Further examination of the changes over time using a CMS and LMS is suggested. We did not evaluate the influence of gender in terms of perception and usage in WebCT. Wong et al. (2012) examined gender differences in computer usage and acceptance by using TAM. Future studies could examine the influence of gender on other attitudes and usage of OLS. Students' social presence and sociability skills and whether these skills influence the manner in which students perceive and utilise resources and their attitude towards system usage can be examined in the context of PRATAM. Fathema, Shannon, and Ross (2015) utilised TAM to study faculty members' LMS usage behaviours in higher education. The revised PRATAM can also be extended to examine the impact of faculty's perception, attitude and sociability to utilising various OLSs.

\section{Acknowledgement}

This study was partially drawn from a 2009 doctoral dissertation completed by the second author, Dr ChengHsin (Alan) Ku, under the advisement of his chair, Dr Stephen A. Sivo. Dissertations details appear in the references. 


\section{References}

Ajzen, I. (1985). From intentions to actions: A theory of planned behavior. In J. Kuhl \& J. Beckmann (Eds.), Action control: From cognition to behavior (pp. 11-39). Berlin: Springer-Verlag.

Bandura, A. (1986). Social foundations of thought and action: A social cognitive theory. Englewood Cliffs, NJ: Prentice-Hall.

Carmines, E. G., \& Zeller, R. A. (1979). Reliability and validity assessment. Beverly Hills, CA: Sage.

Chen, B., Sivo, S., Seilhamer, R., Sugar, A., \& Mao, J. (2013). User acceptance of mobile technology: A campus-wide implementation of Blackboard's Mobile ${ }^{\mathrm{TM}}$ Learn Application. Journal of Educational Computing Research, 49(3), 327-343. https://doi.org/10.2190/EC.49.3.C

Cheng, Y. M., Lou, S. J., Kuo., \& Shih, R. C. (2013). Investigating elementary school students' technology acceptance by applying digital game-based learning to environmental education. Australasian Journal of Educational Technology, 29(1), 96-110. https://doi.org/10.14742/ajet.65

Clay, M. N., Rowland, S., \& Packard, A. (2009). Improving undergraduate online retention through gated advisement and redundant communication. Journal of College Student Retention: Research, Theory \& Practice, 10(1), 93-102. https://doi.org/10.2190/CS.10.1.g

Cobb, P. (1994). Where is the mind? Constructivist and sociocultural perspectives on mathematical development. Educational Researcher, 23(7), 13-20. https://doi.org/10.3102/0013189X023007013

Cronbach, L. J. (1951). Coefficient alpha and the internal structure of tests. Psychometrika, 16, 297-334. https://doi.org/10.1007/BF02310555

D’Ambra, J., Wilson, C. S., \& Akter, S. (2013). Application of the task-technology fit model to structure and evaluate the adoption of E-books by Academics Issue. Journal of the American Society for Information Science and Technology, 64(1), 48-64. https://doi.org/10.1002/asi.22757

Davis, F. D. (1986). A technology acceptance model for empirically testing new end-user information systems: Theory and results. Boston: Massachusetts Institute of Technology.

Davis, F. D., Bagozzi, R. P., \& Warshaw, P. R. (1989). User acceptance of computer technology: a comparison of two theoretical models. Management Science, 35, 982-1003. https://doi.org/10.1287/mnsc.35.8.982

Deng, L., \& Tavares, N. J. (2013). From Moodle to Facebook: Exploring students' motivation and experiences in online communities. Computers \& Education, 68, 167-176. https://doi.org/10.1016/j.compedu.2013.04.028

Diaz, D. P. (2002). Online drop rate revisited. The Technology Source. Retrieved from http://www.technologysource.org/article/online drop_rates revisited/

Doyle, G. J., Garrett, B., \& Currie, L. M. (2014). Integrating mobile devices into nursing curricula: Opportunities for implementation using Rogers' Diffusion of Innovation model. Nurse Education Today, 34(5), 775-782. https://doi.org/10.1016/j.nedt.2013.10.021d

Fan, X., \& Sivo, S. A. (2007). Sensitivity of fit indices to model misspecification and model types. Multivariate Behavioral Research, 42(3), 509-529. https://doi.org/10.1080/00273170701382864

Fallon, C., \& Brown, S. (2003). E-learning standards: A guide to purchasing, developing, and deploying standards-conformant e-learning. Boca Raton, FL: CRC Press.

Fathema, N., Shannon, D., \& Ross, M. (2015). Expanding the Technology Acceptance Model (TAM) to examine faculty use of learning management systems (LMSs) in higher education institutions. MERLOT Journal of Online Learning and Teaching, 11(2), 210-232. Retrieved from http://jolt.merlot.org/Vol11no2/Fathema_0615.pdf

Field, A. P. (2005). Discovering statistics using SPSS (2nd ed.). Thousand Oaks, CA: Sage.

Fishbein, M., \& Ajzen, I. (1975). Belief, attitude, intention and behavior: An introduction to theory and research. Reading, MA: Addison-Wesley.

Garrison, D. R., Anderson, T., \& Archer, W. (2000). Critical inquiry in a text-based environment: Computer conferencing in higher education. The Internet and Higher Education, 2(2-3), 87-105. https://doi.org/10.1016/S1096-7516(00)00016-6

Gautreau, C. (2011). Motivational factors affecting the integration of a Learning Management System by faculty. The Journal of Educators Online, 8(1),1-25. Retrieved from https://www.thejeo.com/archive/2011_8_1/gautreau 
Guiffrida, D. A., Lynch, M. F., Wall, A. F., \& Abel, D. S. (2013). Do reasons for attending college affect academic outcomes? A test of a motivational model from a self-determination theory perspective. Journal of College Student Development, 54(2), 121-139. Retrieved from http://muse.jhu.edu/article/502604

Hatcher, L. (1994). A step-by-step approach to using the SAS system for factor analysis and structural equation modeling. Cary, NC: SAS Institute.

Hendrickson, A. E., \& White, P. O. (1964). Promax: A quick method for rotation to oblique simple structure. British Journal of Statistical Psychology, 17(1), 65-70. https://doi.org/10.1111/j.20448317.1964.tb00244.x

Horvat, A., Dobrota, M., Krsmanovic, M., \& Cudanova, M. (2015). Student perception of Moodle learning management system: A satisfaction and significance analysis. Interactive Learning Environments, 23(4), 515-527. https://doi.org/10.1080/10494820.2013.788033

Hu, L. T., \& Bentler, P. M. (1999). Cutoff criteria for fit indexes in covariance structure analysis: Conventional criteria versus new alternatives. Structural Equation Modeling, 6(1), 1-55. https://doi.org/10.1080/10705519909540118

Huang, E. Y., Lin, S. W., \& Huang, T. K. (2012). What type of learning style leads to online participation in the mixed-mode e-learning environment? A study of software usage instruction. Computers \& Education, 58(1), 338-349. Retrieved from https://www.learntechlib.org/p/50708/

Kaiser, H. (1974). An index of factorial simplicity. Psychometrika, 39(1), 31-36. https://doi.org/10.1007/BF02291575

Kim, M. R. (2008). Factors influencing the acceptance of e-learning courses for mainstream faculty in higher institutions. International Journal of Instructional Technology and Distance Learning, 5(2), 29-44. Retrieved from http://www.itdl.org/Journal/Feb_08/article03.htm

Kinash, S., Brand, J., \& Mathew, T. (2012). Challenging mobile learning discourse through research: Student perceptions of Blackboard Mobile Learn and iPads. Australasian Journal of Educational Technology, 28(4), 639-655. https://doi.org/10.14742/ajet.832

Ku, C. H. (2009). Extending the technology acceptance model using perceived user resources in higher education web-based online learning courses (Doctoral dissertation). Retrieved from http://etd.fcla.edu/CF/CFE0002635/Ku_Cheng-Hsin_200905_PhD.pdf

Lee, Y. C. (2008). The role of perceived resources in online learning adoption. Computers \& Education, 50(4), 1423-1438. https://doi.org/10.1016/j.compedu.2007.01.001

Liu, I. F., Chen, M. C., Sun, Y. S., Wible, D., \& Kuo, C. H. (2010). Extending the TAM model to explore the factors that affect intention to use an online learning community. Computers \& Education, 54(2), 600610. https://www.learntechlib.org/p/67240/

Lu, J., Yu, C. S., \& Liu, C. (2003). Learning style, learning patterns, and learning performance in a WebCTbased MIS course. Information \& Management, 40(6), 497-507. https://doi.org/10.1016/S03787206(02)00064-2

Madden, T. J., Ellen, P. S., \& Ajzen, I. (1992). A comparison of the theory of planned behavior and the theory of reasoned action. Personality and Social Psychology Bulletin, 18, 3-9. https://doi.org/10.1177/0146167292181001

Mathieson, K., Peacock, E., \& Chin, W. W. (2001). Extending the technology acceptance model: the influence of perceived user resources. ACM SIGMIS Database, 32(3), 86-112. https://doi.org/10.1145/506724.506730

Morgan, G. (2003). Faculty use of course management systems: Boulder, CO: EDUCAUSE Center for Applied Research. Retrieved from https://www.educause.edu/ir/library/pdf/ers0302/rs/ers0302w.pdf

Morris, M. G., \& Venkatesh, V. (2010). Job characteristics and job satisfaction: Understanding the role of enterprise resource planning system implementation. MIS Quarterly, 34(1), 143-161. Retrieved from http://dl.acm.org/citation.cfm?id=2017455

Ngai, E. W. T., Poon, J. K. L., \& Chan, Y. H. C. (2007). Empirical examination of the adoption of WebCT using TAM. Computers \& Education, 48(2), 250-267. https://doi.org/10.1016\%2Fj.compedu.2004.11.007

Nora, A., \& Snyder, B. P. (2009). Technology and higher education: The Impact of e-learning approaches on student academic achievement, perceptions and persistence. Journal of College Student Retention: Research, Theory \& Practice, 10(1), 3-19. https://doi.org/10.2190/CS.10.1.b 
Novo-Corti, I., Varela-Candamio, L., \& Ramil-Diaz, M. (2013). E-learning and face to face mixed methodology: Evaluating effectiveness of e-learning and perceived satisfaction for a microeconomic course using the Moodle platform. Computers in Human Behavior, 29, 410-415. https://doi.org/10.1016/j.chb.2012.06.006

Pan, C., Gunter, G., Sivo, S., \& Cornell, R. (2005). End-user acceptance of a learning management system in two hybrid large-sized introductory undergraduate courses. Journal of Educational Technology Systems, 33(4), 355-365. https://doi.org/10.2190/B7TV-X8RN-0L66-XTU8

Pan, C., Sivo, S., Gunter, G., \& Cornell, R. (2005). Students' perceived ease of use of an e-learning management system: An exogenous or endogenous variable? Journal of Educational Computing Research, 33 (3), 285-307. https://doi.org/10.2190/7M4G-R742-W9FT-JX1J

Pan, C. C. (2003). System use of WebCT in the light of the technology acceptance model: A student perspective (Doctoral dissertation). University of Central Florida, FL. Retrieved from https://www.learntechlib.org/p/119445/

Pan, C. C., Sivo, S. A., \& Brophy, J. (2003). Students' attitude in a web-enhanced hybrid course: A structural equation modeling inquiry. Journal of Educational Media and Library Sciences, 41(2), 181-194. Retrieved from http://joemls.dils.tku.edu.tw/detail.php?articleId=41204\&lang=en

Pan, C. C., Sivo, S. A., \& Goldsmith, C. (2016). A prelude to strategic management of an online enterprise. TechTrends, 60(3), 226-232. https://doi.org//10.1007/s11528-016-0042-7

Park, S. Y. (2009). An analysis of the technology acceptance model in understanding university students' behavioral intention to use e-learning. Educational Technology \& Society, 12(3), 150-162. Retrieved from http://www.ifets.info/journals/12_3/14.pdf

Pituch, K. A., \& Lee, Y. K. (2006). The influence of system characteristics on e-learning use. Computers \& Education, 47(2), 222-244. https://doi.org/10.1016/j.compedu.2004.10.007

Porter, G. W. (2013). Free choice of learning management systems: Do student habits override inherent system quality? Interactive Technology and Smart Education, 10(2), 84 -94. Retrieved from https://www.learntechlib.org/p/133299/

Romanov, K., \& Nevgi, A. (2006). Learning outcomes in medical informatics: Comparison of a WebCT course with ordinary web site learning material. International Journal of Medical Informatics, 75(2), 156162. https://doi.org/10.1016/j.ijmedinf.2005.06.004

Saade, R. G., He, X., \& Kira, D. (2007). Exploring dimensions to online learning. Computers in Human Behavior, 23, 1721-1739. https://doi.org/10.1016/j.chb.2005.10.002

Sánchez, R. A., \& Hueros, D. A., Ordaz, G. M. (2013). E-learning and the University of Huelva: A study of WebCT and the technological acceptance model. Campus-Wide Information Systems, 30(2), 135-160. https://doi.org/10.1108/10650741311306318

Shaw, R. S. (2012). A study of the relationships among learning styles, participation types, and performance in programming language learning supported by online forums. Computers \& Education, 58(1), 111-120. Retrieved from https://www.learntechlib.org/p/50701/

Shea, P., Hayes, S., Uzuner-Smith, S., Gozza-Cohen, M., Vickers, J., \& Bidjerano, T. (2014). Reconceptualizing the community of inquiry framework: An exploratory analysis. The Internet and Higher Education, 23, 9-17. https://doi.org/10.1016/j.iheduc.2014.05.002

Shroff, R. H., Deneen, C. C., \& Ng, E. M. W. (2011). Analysis of the technology acceptance model in examining students' behavioural intention to use an e-portfolio system. Australasian Journal of Educational Technology, 27(4), 600-618. https://doi.org/10.14742/ajet.940

Siegel, D. M. (2008). Accepting technology and overcoming resistance to change using the motivation and acceptance model (Unpublished doctoral dissertation). University of Central Florida, FL. Retrieved from http://stars.library.ucf.edu/cgi/viewcontent.cgi?article $=4559 \&$ context $=$ etd

Sivo, S. A., Fan, X., Witta, E. L., \& Willse, J. (2006). The search for “optimal” cutoff properties: Fit index criteria in structural equation modeling. Journal of Experimental Education, 74(3), 267-288. https://doi.org/10.3200/JEXE.74.3.267-288

Sivo, S., \& Pan, C. (2005). Undergraduate engineering and psychology students' use of a course management system: A factorial invariance study of user characteristics and attitudes. The Journal of Technology Studies, 31(2), 94-103. Retrieved from http://www.jstor.org/stable/43604057 
Sivo, S. A., Pan, C. C., \& Brophy, J. (2004). Temporal cross-lagged effects between subjective norms and students' attitudes regarding the use of technology. Journal of Educational Media and Library Sciences, 42(1), 63-74. Retrieved from http://joemls.dils.tku.edu.tw/detail.php?articleId=42106\&lang=en

Sivo, S. A., Pan, C. C., \& Hahs-Vaughn, D. (2007). Combined longitudinal effects of attitude and subjective norms on student outcomes in a web-enhanced hybrid course: A structural equation modeling approach. British Journal Educational Technology,38(5), 861-875. https://doi.org/10.1111/j.14678535.2006.00672.x

Smith, J., \& Sivo, S. A. (2012). Predicting continued use of online teacher professional development and the influence of social presence and sociability. British Journal of Educational Technology, 43(6), 871-882. https://doi.org/10.1111/j.1467-8535.2011.01223.x

Taylor, B. (2016). Student perceptions of quality in online courses using the Community of Inquiry (CoI) Framework (Unpublished doctoral dissertation). California State University, San Marcos, CA. Retrieved from http://hdl.handle.net/10211.3/171299

Traver, A. E., Volchok, E., Bidjerano, T., \& Shea, P. (2014). Correlating community college students' perceptions of community of inquiry presences with their completion of blended courses. The Internet and Higher Education, 20, 1-9. https://doi.org/10.1016/j.iheduc.2013.09.001

Turner, M., Kitchenham, B., Brereton, P., Charters, S., \& Budgen, D. (2010). Does the technology acceptance model predict actual use? A systematic literature review. Information and Software Technology, 52(5), 463-479. https://doi.org/10.1016/j.infsof.2009.11.005

Venkatesh, V., \& Davis, F. D. (2000). A theoretical extension of the technology acceptance model: Four longitudinal field studies. Management Science, 46(2),186-204. https://doi.org/10.1287/mnsc.46.2.186.11926

Venkatesh, V., Morris, M. G., Davis, G. B., \& Davis, F. D. (2003). User acceptance of information technology: Toward a unified view. MIS Quarterly, 27(3), 425-478. Retrieved from http://www.jstor.org/stable/30036540

Visser, P. S., Krosnick, J. A., Marquette, J., \& Curtin, M. (1996). Mail surveys for election forecasting? An evaluation of the Columbus Dispatch poll. Public Opinion Quarterly, 60(2), 181-227. https://doi.org/10.1086/297748

Wei, H. C., Peng, H., \& Chou, C. (2015). Can more interactivity improve learning achievement in an online course? Effects of college students' perception and actual use of a course-management system on their learning achievement. Computers \& Education, 83, 10-21. https://doi.org/10.1016/j.compedu.2014.12.013 0360-1315/

Wells, M. I. (2007). Dreams deferred but not deterred: A qualitative study on undergraduate nursing student attrition. Journal of College Student Retention: Research, Theory and Practice, 8(4), 439-456. https://doi.org/10.2190/17K2-5847-6637-L70P

Willett, H. G. (2002). Not one or the other but both: Hybrid course delivery using WebCT. Electronic Library, 20(5), 413-419. https://doi.org/10.1108/02640470210447847

Wong, K. T., Teo, T., \& Russo, S. (2012). Influence of gender and computer teaching efficacy on computer acceptance among Malaysian student teachers: An extended technology acceptance model. Australasian Journal of Educational Technology, 28(7), 1190-1207. Retrieved from https://www.learntechlib.org/p/44191/

Corresponding author: Stephen A. Sivo, Stephen.Sivo@ucf.edu

Australasian Journal of Educational Technology @ 2018.

Please cite as: Sivo, S. A., Ku, C.-H., \& Acharya, P. (2018). Extending the technology acceptance model using perceived user resources in higher education Web-based online learning courses. Australasian Journal of Educational Technology, 34(4), 72-91. https://doi.org/10.14742/ajet.2806 